\title{
Clinical aspects of neuroregression: our experience on batten disease
}

\author{
Mahesh Kamate \\ From International Conference on Human Genetics and 39th Annual Meeting of the Indian Society of \\ Human Genetics (ISHG) \\ Ahmadabad, India. 23-25 January 2013
}

Neuroregression in a child is an important clinical problem faced by a pediatric neurologist. Depending on the initial clinical features they can be broadly divided into grey matter disorders, white matter disorders or combined. The age of onset and the progression of symptoms also help us in further characterization. Involvement of other systems and neuroimaging findings helps us in formulating the differential diagnosis and guides us in the laboratory evaluation and selection of appropriate confirmatory tests. After brief discussion on the clinical approach to neuroregression, here I would like to present our experience with one of the important poliodystrophies in children- Neuronal ceroid lipofuscinosis.

Neuronal ceroid lipofuscinosis is a group of progressive neurodegenerative disorders characterized by accumulation of ceroid lipopigment in lysosomes in neurons and other cell types. Over a period of four years we have diagnosed 20 children with neuronal ceroid lipofucinosis. Of the 20 patients, 5 had infantile type and 15 had lateinfantile neuronal ceroid lipofuscinosis. Diagnosis was confirmed by appropriate enzyme assay. Clinical presentation was quite varied. Common presenting features included refractory seizures, developmental delay/ regression, and abnormal movements. Visual failure was not common in the present case series, and novel neuroimaging finding in the form of isolated dentate nucleus hyperintensities in PPT related neuronal ceroid lipofuscnioses was noted. During follow-up, all patients had a progressive downhill course and one patient died. Prenatal diagnosis could be offered to one family. Our experience suggests that infantile and late-infantile neuronal ceroid lipofuscinosis is not uncommon in this region of the country and the phenotype is different.

Correspondence: drmaheshkamate@gmail.com

KLES, Belgaum, Karnataka, India

(c) 2014 Kamate; licensee BioMed Central Ltd. This is an Open Access article distributed under the terms of the Creative Commons Attribution License (http://creativecommons.org/licenses/by/2.0), which permits unrestricted use, distribution, and reproduction in any medium, provided the original work is properly cited. The Creative Commons Public Domain Dedication waiver (http:// creativecommons.org/publicdomain/zero/1.0/) applies to the data made available in this article, unless otherwise stated.
doi:10.1186/1755-8166-7-S1-137
Cite this article as: Kamate: Clinical aspects of neuroregression: our Cite this article as: Kamate: Clinical aspects of neuroregression: our
experience on batten disease. Molecular Cytogenetics 2014 7(Suppl 1):137.

Submit your next manuscript to BioMed Central and take full advantage of:

- Convenient online submission

- No space constraints or color figure charges

- Immediate publication on acceptance

- Inclusion in PubMed, CAS, Scopus and Google Scholar

- Research which is freely available for redistribution

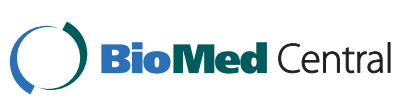

- Thorough peer review

Published: 21 January 2014 www.biomedcentral.com/submit 